\title{
The Educational Supervisor's Performance in Light of Applying the Knowledge Economy in the Education Directorates of Zarqa Governorate in the Hashemite Kingdom of Jordan
}

\author{
Mohammad Salman Fayyad AlKhazaleh ${ }^{* 1}$ and \\ Habes Mohammed Khalifa Hattamleh ${ }^{2}$
}

$\approx$ This study aimed at identifying the performance of the educational supervisor in the light of applying the knowledge economy in the education directorates of the Zarqa Governorate, Jordan. For this purpose, the researchers constructed a study instrument with 35 items distributed over four areas: (educational planning, educational management, teachers' professional growth, and curriculum building). Its validity and reliability were verified and later distributed to the study population, which consisted of 100 educational supervisors. The researchers utilised the descriptive method for its suitability to the study nature. The study found that the performance of the educational supervisor, in the light of applying the knowledge economy concept in the education directorates of the Zarqa Governorate, was medium. Furthermore, there were no statistically significant differences of the effect of the experience and directorate variables on all the study areas. Finally, the researchers made recommendations and suggestions relevant to the results.

Keywords: educational supervisor, directorate, education, educational supervision, knowledge economy

$1{ }^{*}$ Corresponding Author. Al Ain University for Science and Technology - College of Education, United Arab Emirates; dr.mohamadslman@yahoo.com.

2 Faculty of Education, University of Jadara, Jordan. 


\title{
Uspešnost nadzornika izobraževanja $\mathrm{z}$ vidika uporabe gospodarstva, temelječega na intelektualnem kapitalu, v izobraževalnih direktoratih v pokrajini Zarqa v Hašemitski kraljevini Jordaniji
}

\author{
Mohammad Salman Fayyad Alkhazaleh in \\ Habes Mohammed Khalifa Hattamleh
}

$\propto$ Cilj raziskave je bil ugotoviti uspešnost nadzornika izobraževanja $\mathrm{z}$ vidika uporabe gospodarstva, temelječega na intelektualnem kapitalu, $\mathrm{v}$ izobraževalnih direktoratih v pokrajini Zarqa, Jordanija. V ta namen so raziskovalci izdelali instrument s 35 postavkami, razdeljenimi na štiri področja: načrtovanje izobraževanja, vodenje izobraževanja, profesionalni razvoj učiteljev in oblikovanje učnega načrta. Po potrditvi njegove veljavnosti in zanesljivosti so instrument razdelili stotim nadzornikom izobraževanja, ki so sodelovali v raziskavi. Raziskovalci so uporabili deskriptivno metodo, ker je bila primerna glede na naravo raziskave. Raziskava je pokazala srednjo uspešnost nadzornikov izobraževanja $\mathrm{z}$ vidika uporabe koncepta gospodarstva, temelječega na intelektualnem kapitalu, v izobraževalnih direktoratih v pokrajini Zarqa. Poleg tega ni bilo statistično pomembnih razlik glede vpliva izkušenj in spremenljivk direktorata na vsa raziskana področja. Ob koncu so raziskovalci podali priporočila in predloge glede na dobljene rezultate.

Ključne besede: nadzornik izobraževanja, direktorat, izobraževanje, izobraževalni nadzor, gospodarstvo, temelječe na intelektualnem kapitalu 


\section{Introduction}

Educational supervision is an essential sub-system of the educational system in Jordan. It is linked to all the inputs of the educational process that are concerned with building the human mind, emotions, and all aspects of the personality. It is process that is the most closely connected with the educators' professional growth, in general (Al-Soud, 2002), through the supervisor's application of a behavioural system designed to interact with the teaching systems and goal achievement. In this concern, the supervisor provides the widest extent of assistance to the teacher and spares no effort to overcome the obstacles the teacher faces, allows the teacher the opportunity to his/her skills growth, concentration on his/her self-development, and assists in developing the kinds and means of learning. The supervisor can also provide the teacher assistance in teaching methods, educational aids, the art of classroom management, preparing the class tests and questions, making field research to explore the educational problems, developing the lessons, offering model lessons. He/she can contribute in: treating professional problems, making efforts to find solutions and alternatives that contribute to surpass the curricular problems, defining the pupils' problems, their characteristics and needs, helping the teacher to fulfil these needs, linking the school and teacher to the community needs and providing them desired services (Masa'adeh, 2000).

In this regard, Hill (1993) ensures that, in the light of the knowledge economy, the supervisor is required to concentrate on the use of inclusiveness in the objectives and educational and training methods, so that his/her diagnosis will be remedial, preventive, preservative, constructive, and developing.

Therefore, the Ministry of Education in Jordan sought to upgrade the levels of educational supervision and achieve its objectives effectively. It introduced many modern concepts and styles that raise the competence of the supervisor. For instance, it introduced the knowledge economy concept through the ERFKE project (Education Reform for Knowledge Economy). It concentrated on obtaining, sharing, using, employing, innovating, and producing knowledge. It also focuses on the use of the human mind as a valuable knowledge capital and on employing scientific research to create a pool of strategic changes in the nature and organisation of the economic environment. In so doing, it will be more responsive and consistent with the challenges of globalisation, information and communication technology, and the universality of knowledge and sustainable development in its holistic sense (Mrayyan \& Alquda, 2009).

The ERFKE project further supports the concept of the educational supervisors as the first to engage the knowledge revolution and connect it to the 
teachers, because they have the primary role in teaching the students first how to learn and think, instead of teaching them the knowledge itself. So, 'arming the student with how to access knowledge and skills to deal with, in the light of the universal communication revolution, is a matter of utmost importance, instead of cramming abundant information in his/her mind, which may not benefit or enable him/her to assimilate all of it due to the limitations of time (“Research Management", 2002).

Mo'taman (2004) confirms that the knowledge economy (also termed the cognitive economy) requires the ministry to avail supervisors of high levels of academic preparation and training. They should also possess high degrees of enablement, care for professional growth, continuous self-education, and the ability to communicate, innovate, solve problems, and make decisions. The supervisors should possess well-integrated IT skills and be able to successfully employ technology. This is because the knowledge economy focuses on material, human and skill requirements, with which the supervisor should be equipped, in general:

1. It is essential to provide an infrastructure for the computer network and internet services, which provide the ability to realise effective research information and systems. A human environment should be developed to provide a supporting societal structure that will produce a learned community, able to question and link and use innovative thinking skills, on the one hand, and provide the legislative environment with laws and systems that facilitate the shift to a knowledge economy, on the other.

2. It is necessary to build learning on a foundation of creativity, productivity, and confidence and to encourage interactive learning that leads to the creation of enormous innovative abilities.

Al-Nae'emi (2007) indicated that the Ministry of Education, which engages with the knowledge economy, produces educators capable of developing learning and knowledge acquisition, employ, produce and exchange this knowledge. It develops the ability to research, explore and discover, to sponsor and augment the abilities, to accept responsibilities, and to develop mental and innovative abilities in support of excellence and productivity. The Ministry of Education employs information and communication technology. It develops abilities for deep understanding and critical thinking, analysis, education, linking, enhancing the ability to engage in positive dialogue, purposeful discussion, acceptance of others' views, and the ability to create change and development.

In light of this concept, the researchers, through their educational experience and communication with the educational supervisors, noted the 
increase of routine works they are burdened with, and the complaints of some of them regarding this concept and its application mechanism. Therefore, the researchers conducted this study, 'Performance of the educational supervisor in the light of applying the concept of knowledge economy in the directorates of education in Zarqa Governorate.'

Many previous studies dealt with educational supervision; some explored the reality of the supervision; others dealt with the obstacles of the supervision, as well as the role of the supervisor in improving the teaching process and developing and qualifying the teachers. However, the researchers did not find a study with the subject of the current study, despite the shift of the Ministry of Education to apply cognitive economy in its educational directorates and focus on preparing and equipping the supervisors in the light of the knowledge economy concept. Thus, the researchers chose the studies that are closely related to this current study as shown below.

Al-Qateefi (1994), conducted a study titled 'Problems of the Educational Supervision in the Public Secondary Girls' Schools in the City of Riyadh, Saudi Arabia.' The study sample comprised 50 female supervisors, and the researcher employed the questionnaire for data collection. She concluded by determining the reasons that prevent achieving the supervision objectives, which included poor training of the educational supervisors, high numbers of the teachers they are required to supervise, and excessive managerial works that impede the supervisors from diversifying their supervision methods.

Al-Zagha (1998) made a study about the reality of the educational supervision on the West Bank, as viewed by the educational supervisors and teachers of the secondary stage. The study sample consisted of 36 supervisors and (200) teachers, and the researcher found many major problems facing the educational supervisor when applying modern and various supervision methods.

Narango (2000) conducted a study titled, 'Educational Supervision in British Columbia, Canada, and the Role of the Supervisor as Viewed by the Teachers.' The sample consisted of 1345 teachers, and the results emphasised the necessity of accurately defining practices and styles required from the supervisor. The study recommended the ministry to take the role of the director and planner for this supervisor so that educational supervision would not lose its effect in the educational process service.

Pajak (2002) made a study to identify the importance of the supervision tasks that the educational supervisors practice, which consisted of 1620 educational supervisors. The results showed that the most practiced supervisors' assignments are communication, teacher development, planning, participation in conferences, authoring the curricula, problem-solving, decision taking, and 
relations with the local community. The results further showed that all the areas were highly valued by the supervisors.

William (2005) conducted a study in Toronto Canada titled, 'Raising the Promotion Condition for Upgrading to the Position of Supervisor', in which he sought to identify the views about promotion to the position of the educational supervisor as a career. The sample consisted of 55 male and female supervisors, and the results showed a need to train the new supervisors, teach them modern supervision methods, and educate them about their responsibilities.

Beach (2007) surveyed the perceptions of the teachers, school principals and educational supervisors of the public schools in Tennessee, USA, about the education services the supervisor carries out, regarding classroom observations, and meetings held following this observation. The sample comprised 381 teachers and 317 supervisors, randomly chosen. The study results showed that the performance and services provided by the educational supervisor are characterised by failure, inability to achieve the optimal results and that poor planning in supervision makes it incapable of solving the educational problems.

Atari (2007) conducted a study aimed at identifying the tasks and concepts the supervisor should carry out, as viewed by the teachers and supervisors in the State of Qatar. The study sample consisted of 80 teachers, and the results showed that there is no sufficient time for the supervisor to assist the teachers, due to the heavy managerial workloads with which he is burdened.

The study of Al-Hailat and Alquda (2008) aimed to identify whether the education supervisors in Jordan possess concepts of the cognitive economy. The sample consisted of 213 educational supervisors in different education directorates in the kingdom. The results showed that the educational supervisors possess a high degree of knowledge about the knowledge economy proportional to the subjects they supervise and that they were in favour of the scientific subjects. The results did not show statistically significant differences in the educational supervisors' possession degree of knowledge economy concepts attributed to the experience variable.

Alhulu (2009) conducted a study aimed at identifying the educational supervisors' practice degree of the supervision styles in Palestinian schools; the sample consisted of 565 male and female teachers. The results showed that the general educational supervisors' degree of practising the supervision styles with the study sample was medium; and that there are statistically significant differences attributed to the experience variable, in favour of those with 10 and more years of experience.

Altwaisi (2014) conducted a study aimed at identifying the vocational education teachers' degree of practising the cognitive economy competences 
as viewed by the educational supervisors in Jordan. The results showed that the practice degree was medium, and there were statistically significant differences ascribed to the experience variable in the educational supervision, in favour of supervisors with recent experience.

The review of the previous studies, including both more recent and older ones relevant to the study topic, directly or indirectly, showed that all of them tackled a part of our study subject. Some dealt in the supervision styles, tasks, and services the supervisors practice, such as the studies of Alhulu (2009), Pajak (2002), Beach (2007), Atari (2007), and Narango (2000). Other studies emphasised the necessity of training and educating the supervisors on recent styles, such as the study of William (2005). Others focused on the reality of educational supervision, such as Al-Zagha (1999). Finally, the study of Al-Hailat and Alquda (2008) explored the Jordanian Ministry of Education supervisors' possession degree of the knowledge economy concept. However, most of the previous study samples consisted of supervisors, teachers, and school principals; meanwhile, the current study focus was to identify the teaching performance of the educational supervisor in light of applying the knowledge economy in the education directorates in Zarqa, the Hashemite Kingdom of Jordan. It should be noted that the researchers benefited from the previous studies in discussing, interpreting, and analysing the results of the current study.

\section{Objectives}

This study aimed to:

1. Identify the educational supervisor's performance in the light of applying the knowledge economy concept in the directorates of education in Zarqa Governorate, Jordan.

2. Identify differences in the educational supervisor's performance degree, in the light of applying the knowledge economy concept in the directorates of education in Zarqa Governorate, ascribed to directorate and experience variables.

\section{Study Significance}

The significance of this study stems from the importance of the stage it dealt with and the problem it treated. In this concern, the educational supervisor is a most important component for developing and modernising the teaching/learning process. The importance of the study also stems from what the supervisor offers the teacher, which, in turn, would be reflected on the students 
in the classroom, in the form of new and diversified teaching methods and factors that help in learning and perfecting achievement.

The problem it tackles lies in the study's attempt to link what happens in the education field in Jordan, such as courses and programmes carried out by the supervisors to provide service to the field, on one hand; with what is offered by the Ministry of Education in the diversification of styles and methods to qualify the supervisors and realise their professional growth, on the other.

The ministry's adoption of the knowledge economy concept requires a new 'dealing with knowledge', and how to employ the supervisors to assist and develop the teacher. This will be reflected in the classroom and in achieving growth in the student's personality, which enables him/her to 'generate' knowledge.

Qualifying the educational supervisor and equipping him with the most up-to-date methods, to become able to serve both the teachers and students accordingly, require assurance from the Ministry of Education to allow the supervisor a space to apply his educational role, within the framework of high quality educational concepts, leading to the development of the teaching-learning process. The importance of this study is also highlighted by the efforts the Ministry of Education makes to achieve the objectives of the knowledge economy. This calls for ensuring the efficiency and ability of the supervisors to gain the benefit of these abilities, as well as assuring the validity of their qualification course to serve the ministry's objectives in creating the desired shift.

\section{Study Problem}

The educational supervisor is a most important component in the Ministry of Education, relied upon in improving, controlling and upgrading the teaching/learning process. As such, the ministry has made efforts to introduce whatever is new and modern to the supervision system. For example, it introduced the knowledge economy concept to the system; to increase the competency of the supervisor and enable him to perform his role in the fullest and most modern manner. Nonetheless, the researcher, through meeting a number of supervisors, noted their complaints of the heavy routine workloads. They considered them negative, rather than positive, components for their performance, hindering their advancement, and do not realise the desired objectives of the Ministry through employing the knowledge economy; thus, impeding the development and improvement of the teaching-learning process. In connection with this, identifying and diagnosing the problems may contribute to the treatment of them, and put them on the right track. Accordingly, this study was made to identify the educational supervisor's performance in the light of 
applying the knowledge economy concept in Zarqa Education Directorates, through answering the following questions:

1. What is the educational supervisor's performance in the light of applying the knowledge economy concept in Zarqa Governorate Education Directorates?

2. Does the supervisor's performance, in the light of applying the concept of the knowledge economy concept in Zarqa Governorate Education Directorates, differ by the Directorate and Experience Variable?

\section{Terminology}

Educational Supervisor: an educational leader seeks, with all stakeholders of the teaching/learning process, to optimise and develop this process.

Knowledge economy: knowledge selection and innovation, and choosing what would be employed to improve the teaching/learning process; realise upgrading of the educational system, through utilising the human mind; applying scientific research and different thinking styles, and information technology to bring about the aspired economic and social changes (Al-Khawaldeh, 2009).

\section{Study Limits}

1. Spatial Limits: the study was applied in the educational directorates of Zarqa Governorate: Zarqa/1, Zarqa/2, and Ruseifa education directorates.

2. Time Limits: the second semester of the 2015/16 academic year.

3. Human Limits: study population was limited to the educational supervisors in the three education directorates in Zarqa Governorate.

4. Methodological Limits: results of this study are defined by the accuracy of its individuals' responses on the supervision areas determined for the study purposes, namely: educational planning, educational management, professional growth, and curriculum. The results were determined by indications of the study instrument, in terms of its validity, reliability and procedures used.

\section{Sample}

The study population consisted of all the educational supervisors working in the three abovementioned education directorates in Zarqa Governorate $(n=140)$. 
The study sample consisted of 40 supervisors in the Zarqa/1 education directorate, 32 in Zarqa/2, and 28) in the Ruseifa directorate, as shown in Table 1.

Table 1

Distribution of the educational supervisors based on the variables (directorate and experience)

\begin{tabular}{lccc}
\hline \multirow{2}{*}{ Directorate Variable } & \multicolumn{2}{c}{ Experience Variable } & \multirow{2}{*}{ No. } \\
\cline { 2 - 3 } & 1-5 Years & More than 5 years & \\
\hline Directorate of Education/1 & 22 & 18 & 40 \\
Directorate of Education/1 & 17 & 15 & 32 \\
Directorate of Education/ Russeifa & 18 & 10 & 28 \\
\hline Total & 57 & 43 & 100 \\
\hline
\end{tabular}

\section{Study Instrument}

To achieve the study objective, the researchers reviewed the educational literature related to the educational supervision and cognitive economy, as well as reviewing measures and questionnaires of previous studies. They paraphrased 35 items to measure the educational supervisor's performance in the light of applying knowledge economy, as viewed by the supervisors. The items were distributed at different rates over four (4) areas: educational planning, educational management, professional growth, and curriculum.

\section{Instrument Validity and Reliability}

To ensure validity, the study instrument was presented to a committee of arbitrates and specialists of the Jordanian universities professors and educational supervisors of the Ministry of Education. The agreement rate was $88 \%$, and their comments were taken into account to amend or delete certain items. The instrument, in its final shape, consisted of 35 items distributed over four areas.

As for reliability, the researchers employed the two-halves split method, i.e., dividing the items into two groups: odd number items and even number items. The researchers calculated the grades of every supervisor on the odd items and even items. Thereafter, they calculated the correlation coefficient between the two grades, which was o.86; a high coefficient, suitable for the purposes of the study. 


\section{Study Variables}

The study had the following variables:

1. Independent variables: the descriptive variables consisting of:

- The directorate: three levels (Zarqa/1, Zarqa/2, and Ruseifa Directorates).

- Experience: two levels (1-5 years and more than 5 years).

2. Dependent variables: are those following the independent variables, with effects on the study results. In this research, they are the responses of the individuals and their evaluation of the supervisor's performance level, in the light of applying the knowledge economy concept in the education directorates, measured by the realised degree on every area of the study instrument.

\section{Statistical processing}

To answer the study questions, the data were entered into the SPSS software, as well as the use of the descriptive statistical method, i.e., means (Ms) and standard deviations (SDs). The researchers further applied appropriate explanatory methods that included the two-way ANOVA, to identify the teaching performance of the educational supervisor, in the light of applying the knowledge economy concept in Zarqa Governorate education directorates (Jordan).

\section{Results Extraction}

The researchers applied the instrument and employed a five-grade evaluation scale to indicate the performance degree of the educational supervisor. The highest grade is 5 , and the lowest is 1 ; when the minimum represents 1 grade, then 0.8 is added to every grade, and the grades are arranged in descending order $(5,4,3,2$, and 1$)$. As such, the weights of the items became as follows: $1-1.8=$ Very Low; 1.81-2.6 = Low; $2.61-3.4=$ Medium; 3.41-4.2 = High and 4.21-5 = Very High.

\section{Results and Discussion}

Questions One: What is the educational supervisor's performance in the light of applying the knowledge economy concept in Zarqa Governorate Education Directorates? 
Ms and SDs of each area of the study were obtained for answering this question, as shown in Table 2.

Table 2

Means and Standard Deviations of Each area of Study in a Descending Order by Ms

\begin{tabular}{llccc}
\hline No. & Area & M & SD & Rank \\
\hline 1 & Educational Planning & 3.33 & .35 & 1 \\
2 & Professional Growth & 3.24 & .46 & 2 \\
3 & Curricula & 3.22 & .60 & 3 \\
4 & Educational Management & 3.05 & .36 & 4 \\
\hline Total & & 3.21 & .26 & \\
\hline
\end{tabular}

Table 2 shows that the highest mean was 3.33 in favour of the educational planning area, reflecting a medium degree; and the lowest mean was 3.05 in favour of the educational management, also reflecting a medium degree. Furthermore, all the means of the responses about the supervisor's performance areas were medium; indicating the presence of obstacles hindering the educational supervisors in performing the desired roles. The researchers explain this by the fact that the currently applied supervision plans in the education directorates do not include, in most of their aspects, knowledge economy-related concepts, which ensure knowledge generation and production in a manner far from monotonous and routine works. This calls for a revision, amendment of the plans, and underpinning the role of the supervisor within a clear, purposeful and systematic vision, which leads to the promotion of the educational field, and achieves the efficiencies, skills and knowledge required by the cognitive economy. This study differs from that of Al-Hailat and Alquda (2008), which indicated that the supervisors possess concepts of the knowledge economy to a high degree.

To reveal the content of each area of the educational supervisors' performance, the researchers obtained Ms and SDs of the items of each domain as follows:

- $\quad$ First Area: Educational planning: as shown in Table 3. 
Table 3

Ms, SDs and Ranks of the Sample Individuals' Responses on the Educational Planning Area

\begin{tabular}{|c|c|c|c|c|}
\hline No & Item & M & SD & Rank \\
\hline 1 & $\begin{array}{l}\text { The educational supervisor uses a clear educational plan depend- } \\
\text { ing on knowledge economy standards. }\end{array}$ & 3.29 & 1.09 & 5 \\
\hline 2 & $\begin{array}{l}\text { He uses a plan based on teachers' requirements in the field and } \\
\text { knowledge economy standards }\end{array}$ & 3.22 & 1.011 & 8 \\
\hline 3 & $\begin{array}{l}\text { He uses a comprehensive supervisory plan taking into account } \\
\text { the concept of the knowledge economy and its objectives }\end{array}$ & 3.35 & 1.20 & 3 \\
\hline 4 & $\begin{array}{l}\text { He uses educational facilities in which he can achieve the objec- } \\
\text { tives of the knowledge economy }\end{array}$ & 3.16 & 1.43 & 10 \\
\hline 5 & $\begin{array}{l}\text { He uses the knowledge economy vision to follow up teachers' } \\
\text { plans on a daily basis. }\end{array}$ & 3.23 & 1.23 & 7 \\
\hline 6 & $\begin{array}{l}\text { He uses knowledge economy vision to participate with the } \\
\text { school administration in developing school-related plans }\end{array}$ & 3.18 & 1.45 & 9 \\
\hline 7 & $\begin{array}{l}\text { He uses the knowledge economy vision to develop prior planning } \\
\text { between him and the teacher about classroom visits. }\end{array}$ & 3.30 & 1.24 & 4 \\
\hline 8 & $\begin{array}{l}\text { He uses the knowledge economy vision to focus on means of } \\
\text { modern technology that help him to develop a plan, train teach- } \\
\text { ers, and the like. }\end{array}$ & 3.27 & 1.37 & 6 \\
\hline 9 & $\begin{array}{l}\text { He uses the knowledge economy vision to find proportionality } \\
\text { between the number of supervisors and number of teachers they } \\
\text { are required to supervise. }\end{array}$ & 3.55 & 1.13 & 1 \\
\hline 10 & $\begin{array}{l}\text { He uses the knowledge economy vision to adhere to the opera- } \\
\text { tional plan related to performance development. }\end{array}$ & 3.45 & 1.19 & 2 \\
\hline \multicolumn{2}{|c|}{ Area as a Whole } & 3.33 & .35 & \\
\hline
\end{tabular}

The above table shows that the means of this area ranged between 3.163.55; and item No. 9 providing, 'Educational supervisor uses the knowledge economy vision to find proportionality between the number of supervisors and number of teachers they are required to supervise' ranked first, followed by item No. 10 with a 3.45 mean. In contrast, item No. 4 providing, 'The supervisor uses educational facilities in which he can achieve the objectives of the knowledge economy', came last with a 3.16 mean. The overall mean of the domain was 3.33, indicative of the medium degree of educational performance. The researchers ascribe this to the fact that planning mainly takes the theoretical dimension in terms of plan preparation, inclusiveness and suitability to the knowledge economy concept. Then, it is taken for granted that every supervisor will have his annual plan that fits the knowledge economy. 
- $\quad$ Second Area: Educational management: Table 4 shows the Ms and SDs of the items of this area.

Table 4

Ms, SDs and Ranks of the Sample Individuals Responses on the Items of the Educational Management Area

\begin{tabular}{llccc}
\hline No & Item & M & SD & Rank \\
\hline 11 & $\begin{array}{l}\text { The educational supervisor uses the knowledge economy vision } \\
\text { to participate with the directorate of education when making } \\
\text { administrative and technical transference among teachers. }\end{array}$ & 2.98 & 1.01 & 6 \\
\hline $12 \quad \begin{array}{l}\text { He uses transportation means, which focus on the knowledge } \\
\text { economy, to enable him to go to any school, any time. }\end{array}$ & 3.07 & .91 & 3 \\
\hline $13 \quad \begin{array}{l}\text { He uses the knowledge economy vision to perform administration } \\
\text { and teaching work within his specialisation. }\end{array}$ & 3.14 & .86 & 2 \\
\hline $14 \quad \begin{array}{l}\text { He uses the knowledge economy vision to participate in decision } \\
\text { making between him and the highest authority in the directorate. }\end{array}$ & 2.95 & .87 & 7 \\
\hline $15 \quad \begin{array}{l}\text { He uses knowledge economy vision to employ the foundations of } \\
\text { public relations between him and teachers. }\end{array}$ & 3.17 & .59 & 1 \\
\hline $16 \quad \begin{array}{l}\text { He uses the knowledge economy vision to receive teachers in his } \\
\text { office at the directorate. }\end{array}$ & 3.00 & .82 & 5 \\
\hline $17 \quad \begin{array}{l}\text { He uses his role in the knowledge economy to consider his opin- } \\
\text { ion with respect to the validity or invalidity of the teacher. }\end{array}$ & 3.04 & .85 & 4 \\
\hline Area as a Whole & 3.50 & .36 & \\
\hline
\end{tabular}

In Table 4, the means of this area ranged between 2.95 and 3.17, with item 15. 'Educational supervisor uses the knowledge economy vision to employ the basics of public relations between him and teachers', ranked first with the highest mean, at 3.17, followed by item 13 with a 3.14 mean. Meanwhile, item 14, 'Educational supervisor uses the knowledge economy vision to participate in decision making between him and the highest authority in the directorate, ranked seventh and last with a 2.95 mean. The overall mean of the domain was 3.05 , implying a medium degree of educational performance. The researchers believe that this result does not match the aspirations of the Ministry of Education to obtain good results through applying the cognitive economy concept. This may be ascribed to the fact that the educational management domain needs to link the education directorate to the practical realities in the educational field. This could be achieved by the effective participation of the educational supervisor, taking his view in all the educational affairs that concern management, for instance, transferring a teacher from one school/directorate to another, or a teacher's unsuitability for teaching, and other educational affairs, in which the 
knowledge economy emphasises highlighting the teaching performance of the educational supervisor.

- Third Area: Teachers' professional growth: as illustrated in Table 5.

Table 5

Ms, SDs and Ranks of the Sample Individuals Responses on the Items of the Educational Professional Growth Domain

\begin{tabular}{|c|c|c|c|c|}
\hline No & Item & $M$ & SD & Rank \\
\hline 18 & $\begin{array}{l}\text { The supervisor uses modern supervisory methods of the knowl- } \\
\text { edge economy concept. }\end{array}$ & 3.00 & .52 & 8 \\
\hline 19 & $\begin{array}{l}\text { He uses the knowledge economy vision to perform various courses } \\
\text { in all disciplines. }\end{array}$ & 3.22 & .55 & 4 \\
\hline 20 & $\begin{array}{l}\text { He uses his role in the knowledge economy to brief teachers on } \\
\text { the international supervisory methods related to the knowledge } \\
\text { economy. }\end{array}$ & 3.56 & 1.44 & 1 \\
\hline 21 & $\begin{array}{l}\text { He uses the knowledge economy vision to hold training courses } \\
\text { for teachers to train them on curriculum regarding the knowledge } \\
\text { economy }\end{array}$ & 3.15 & 1.67 & 6 \\
\hline 22 & $\begin{array}{l}\text { He uses the knowledge economy vision to present an outstanding } \\
\text { teacher to obtain personal incentives to contribute to professional } \\
\text { growth }\end{array}$ & 3.04 & 1.45 & 7 \\
\hline 23 & $\begin{array}{l}\text { He uses the knowledge economy vision to support the teachers } \\
\text { during his visit to the field }\end{array}$ & 3.45 & 1.34 & 2 \\
\hline 24 & $\begin{array}{l}\text { He uses the knowledge economy vision to conduct educational } \\
\text { research that serves the educational field. }\end{array}$ & 3.30 & 1.50 & 3 \\
\hline 25 & $\begin{array}{l}\text { He uses the knowledge economy vision to apply standards that } \\
\text { distinguish between creative and uncreative teachers. }\end{array}$ & 3.20 & 1.31 & 5 \\
\hline \multicolumn{2}{|c|}{ Domain as a Whole } & 3.24 & .46 & \\
\hline
\end{tabular}

Table 5 shows the Ms and SDs of the sample individuals' responses on every item of the professional growth domain, which means ranged between 3.00 and 3.56. Item 20, 'Educational supervisor uses his role in knowledge economy to brief teachers on the international supervisory methods related to knowledge economy', ranked first, at a 3.56 mean, followed by item 23 with a 3.45 mean. In contrast, item 18 , 'The supervisor uses modern supervisory methods of knowledge economy concept', came in the eighth and last place with a 3.00 mean. The overall mean of the domain was 3.24, reflecting a medium degree of the educational supervisor's performance. The researchers ascribe this to the constraints on the supervisors limiting their willingness to join educational professional development courses for them and the teachers they supervise. It could be further ascribed to the low morale and material return, and confining 
their performance to the routine side that does not include all the objectives for which the knowledge economy concept calls.

- $\quad$ Fourth area: Building the educational curricula, as shown in Table 6.

Table 6

Ms, SDs, and Ranks of the Sample Individuals Responses on the Items of the Educational Curriculum Building Domain

\begin{tabular}{|c|c|c|c|c|}
\hline No & Item & M & SD & Rank \\
\hline 26 & $\begin{array}{l}\text { The supervisor uses the knowledge economy vision to establish } \\
\text { the modern educational curriculum. }\end{array}$ & 3.02 & 1.27 & 7 \\
\hline 27 & $\begin{array}{l}\text { He uses the knowledge economy vision to establish a curriculum } \\
\text { based on the objectives of the knowledge economy. }\end{array}$ & 3.01 & 1.33 & 8 \\
\hline 28 & $\begin{array}{l}\text { He uses the knowledge economy vision to ensure that the } \\
\text { curriculum includes Bloom's (knowledge, psychomotor, and } \\
\text { emotional) domains }\end{array}$ & 3.19 & 1.47 & 5 \\
\hline 29 & $\begin{array}{l}\text { He uses the knowledge economy vision to establish a curriculum } \\
\text { based on the growth stages of students. }\end{array}$ & 3.72 & 1.30 & 1 \\
\hline 30 & $\begin{array}{l}\text { He uses the knowledge economy vision to ensure that the cur- } \\
\text { riculum includes educational activities that serve the educational } \\
\text { concept of the knowledge economy. }\end{array}$ & 3.38 & 1.33 & 3 \\
\hline 31 & $\begin{array}{l}\text { He uses the knowledge economy vision to avoid unnecessary } \\
\text { tautology in the curriculum. }\end{array}$ & 3.14 & 1.33 & 6 \\
\hline 32 & $\begin{array}{l}\text { He uses the knowledge economy vision in establishing the cur- } \\
\text { riculum in logical sequence. }\end{array}$ & 2.99 & 1.42 & 9 \\
\hline 33 & $\begin{array}{l}\text { He uses the knowledge economy vision to harmonise the curricu- } \\
\text { lum and the time allocated for its implementation. }\end{array}$ & 3.27 & 1.28 & 4 \\
\hline 34 & $\begin{array}{l}\text { He uses the knowledge economy vision to stress the curriculum's } \\
\text { commitment to take into account the individual differences. }\end{array}$ & 3.52 & 1.40 & 2 \\
\hline 35 & $\begin{array}{l}\text { He uses the knowledge economy vision to put forward amend- } \\
\text { ments suggested by teachers about the curriculum to the direc- } \\
\text { torate of the curricula. }\end{array}$ & 2.97 & 1.32 & 10 \\
\hline \multicolumn{2}{|c|}{ Domain as a Whole } & 3.22 & .60 & \\
\hline
\end{tabular}

Table 6 shows that the means ranged between 2.97 and 3.72, and item 29, 'Educational supervisor uses the knowledge economy vision to establish a curriculum based on the growth stages of students', ranked first with a 3.72 mean. Item 35, 'Educational supervisor uses the knowledge economy vision to put forward amendments suggested by teachers about the curriculum to the directorate of the curricula, was in the tenth and last place, with a 2.97 mean. Finally, the domain as a whole had a 3.22 mean, which means that the educational supervisor's performance is of medium degree. Such results may be attributed to the fact that the supervisors are not consulted in formulating the 
curriculum. Sometimes, both the supervisor and teacher may be surprised by substituting the applied curriculum with a completely readymade one; and are required to follow the new one without having any role in developing it. In addition, the curriculum, even if based on the knowledge economy concept, is faced with many hindrances during application at schools. For instance, the rarity of scientific subject labs and libraries, lack of sufficient computer labs, the poor performance of some teachers at times, and poor or no activation of the curriculum at other times.

Question Two: Does the supervisor's performance, in the light of applying the concept of the knowledge economy concept in Zarqa Governorate Education Directorates differ according to the Directorate and Experience Variable?

To answer this question, the researchers obtained the Ms and SDs as per the experience and directorate variables, as shown in Table 7.

Table 7

Means and Standard Deviations for the Areas of the Experience and Directorate Variables on the Educational Planning, Professional Growth, Curriculum, and Educational Management

\begin{tabular}{|c|c|c|c|c|c|c|c|c|c|}
\hline \multirow{2}{*}{$\begin{array}{l}\text { Variables } \\
\text { Experience }\end{array}$} & \multirow{2}{*}{ Areas } & \multicolumn{2}{|c|}{$\begin{array}{l}\text { Educational } \\
\text { Planning }\end{array}$} & \multicolumn{2}{|c|}{$\begin{array}{l}\text { Professional } \\
\text { Growth }\end{array}$} & \multicolumn{2}{|c|}{ Curriculum } & \multicolumn{2}{|c|}{$\begin{array}{l}\text { Educational } \\
\text { Management }\end{array}$} \\
\hline & & M & SD & M & SD & $M$ & SD & M & SD \\
\hline $1-5$ & \multirow{2}{*}{ Zarqa/1 } & 8.95 & 50.97 & 5.03 & 40.88 & 6.83 & 39.77 & 5.26 & 37.78 \\
\hline More than 5 & & 6.33 & 54.56 & 4.99 & 42.19 & 6.02 & 40.55 & 6.13 & 38.12 \\
\hline $1-5$ & \multirow{2}{*}{ Zarqa/2 } & 6.00 & 51.88 & 4.89 & 42.66 & 5.65 & 41.44 & 4.98 & 40.88 \\
\hline More than 5 & & 3.77 & 47.14 & 5.13 & 40.54 & 4.98 & 44.22 & 3.67 & 45.20 \\
\hline $1-5$ & \multirow{2}{*}{ Ruseifa } & 9.10 & 44.15 & 6.23 & 43.11 & 5.39 & 41.76 & 7.13 & 42.53 \\
\hline More than 5 & & 5.12 & 43.58 & 5.11 & 42.89 & 5.75 & 40.89 & 5.44 & 41.67 \\
\hline $1-5$ & \multirow{2}{*}{ Overall } & 6.99 & 53.11 & 5.02 & 42.13 & 6.71 & 40.22 & 5.98 & 39.57 \\
\hline More than 5 & & 4.14 & 48.23 & 7.21 & 39.11 & 5.49 & 41.55 & 5.74 & 41.17 \\
\hline
\end{tabular}

To identify the effect of the differences, analysis of variance (ANOVA) was employed for the experience and directorate variables on the four domains (educational planning, professional growth, curriculum, and educational management). Table 8 illustrates this. 
Table 8

ANOVA-Test for Educational Planning, Professional Development, Curriculum, and Educational Management

\begin{tabular}{|c|c|c|c|c|c|c|}
\hline Areas & Source of Variance & $\begin{array}{c}\text { Sum of } \\
\text { squares (SS) }\end{array}$ & $\begin{array}{l}\text { Freedom } \\
\text { Degree }\end{array}$ & $\begin{array}{l}\text { Squares' } \\
\text { Mean }\end{array}$ & $\mathrm{T}$ & $\begin{array}{l}\text { Sig. } \\
\text { Level }\end{array}$ \\
\hline \multirow{5}{*}{$\begin{array}{l}\text { Educational } \\
\text { Planning }\end{array}$} & Experience & .277 & 1 & .277 & .003 & .794 \\
\hline & Directorate & 56.362 & 2 & 28.181 & .451 & .556 \\
\hline & $\begin{array}{l}\text { Interaction between } \\
\text { experience and the } \\
\text { directorate. }\end{array}$ & 202.681 & 2 & 101.341 & 1.585 & .326 \\
\hline & Error & 3989.134 & 98 & 40.705 & & \\
\hline & Total & 4241.547 & 103 & & & \\
\hline \multirow{5}{*}{$\begin{array}{l}\text { Professional } \\
\text { Growth }\end{array}$} & Experience & 7.405 & 1 & 7.405 & .209 & .313 \\
\hline & Directorate & 6.88 & 2 & 3.44 & .002 & .767 \\
\hline & $\begin{array}{l}\text { Interaction between } \\
\text { experience and the } \\
\text { directorate. }\end{array}$ & 24.44 & 2 & 12.22 & 1.135 & .250 \\
\hline & Error & 687.835 & 98 & & & \\
\hline & Total & 722.211 & 103 & & & \\
\hline \multirow{5}{*}{ Curriculum } & Experience & 12.778 & 1 & 12.778 & .388 & .675 \\
\hline & Directorate & 24.880 & 2 & 12.44 & .375 & .532 \\
\hline & $\begin{array}{l}\text { Interaction between } \\
\text { experience and the } \\
\text { directorate. }\end{array}$ & 44.423 & 2 & 22.211 & .631 & .512 \\
\hline & Error & 2123.503 & 98 & 21.668 & & \\
\hline & Total & 2201.223 & 103 & & & \\
\hline \multirow{5}{*}{$\begin{array}{l}\text { Educational } \\
\text { Management }\end{array}$} & Experience & 24.132 & 1 & 24.132 & .824 & .813 \\
\hline & Directorate & 4.156 & 2 & 2.078 & .067 & .277 \\
\hline & $\begin{array}{l}\text { Interaction between } \\
\text { experience and the } \\
\text { directorate. }\end{array}$ & 14.089 & 2 & 7.045 & .257 & .370 \\
\hline & Error & 1712.585 & 98 & 17.475 & & \\
\hline & Total & 1775.179 & 103 & & & \\
\hline
\end{tabular}

Table 8 did not show statistically significant differences ascribed to the experience or directorate variables in the four domains (educational planning, professional growth, curriculum, and educational management).

\section{Discussion of the data in Table 7}

The results of Table 7 show that supervisors with one to five years of experience obtained a total mean of 53.11, in comparison to the mean of 48.23 
for those with more than five years of experience. In the Zarqa/1 variable, those with more than five years of experience had a mean higher than those with one to five years of experience. In the Zarqa/2 and Ruseifa directorates, supervisors with one to five years of experience had higher means than those with more than five years. A 51.88 mean was obtained in Zarqa/2 by those with one to five years of experience, while the mean of those with more than five years of experience was 47.14. In the Ruseifa directorate, the mean of the supervisors with one to five years of experience was 44.15, while the mean of those with more than five years was 43.58 .

As for the total means of the supervisors' professional growth domain, it was higher for those with one to five years of experience than those with more than five years (42.13 vs 39.11). In Zarqa/1, the mean of the supervisors with more than five years of experience was higher than those with one to five years; (42.19 vs 40.88). In contrast, in the Zarqa/2 and Ruseifa directorates, those with one to five years of experience had means higher than those with more than five years of experience: 42.66 vs 40.54 in Zarqa/2 and 43.11 vs 42.89 in Ruseifa.

In the curriculum area, the total mean of the supervisors with more than five years of experience was higher than those with one to five years; (41.55 vs 40.22). In the Zarqa/1 and Zarqa/2 directorates, the means of the supervisors with (more than five years of experience was higher than the supervisors with one to five years: 40.55 vs 39.77 in Zarqa/1, and 44.22 vs 41.44 in Zarqa /2. In the Ruseifa directorate, in contrast, supervisors with one to five years of experience had more means than those with more than five years: 41.76 vs 30.89 .

Finally, in the educational management domain, the total means of the educational supervisors with more than five years of experience were higher than those with one to five years: 41.17 vs 39.57 . As for the variables Zarqa/1 and Zarqa/2, the means of supervisors with more than five years of experience were higher than those with one to five years: 45.20 vs 38.12 and 40.88 vs 37.78 , respectively. In contrast, the supervisors in the Ruseifa directorate with one to five years of experience obtained higher means than those with more than five years 42.53 vs 41.67 .

Regarding the domains as a whole (educational planning, professional growth, curriculum and educational management), the researchers extracted the Ms and SDs by two variables: directorate (Zarqa/1, Zarqa/2 and Ruseifa) and experience (1-5 years and more than 5 years). 
Table 9

Results of the Respondents in All Areas of Study

\begin{tabular}{llcc}
\hline Directorate & Experience & M & SD \\
\hline \multirow{2}{*}{ Zarqa/1 } & 1-5 years & 169.4 & 18.22 \\
& More than 5 years & 175.42 & 16.11 \\
\hline \multirow{2}{*}{ Zarqa/2 } & 1-5 years & 176.86 & 16.88 \\
& More than 5 years & 177.1 & 14.55 \\
\hline \multirow{2}{*}{ Ruseifa } & 1-5 years & 171.55 & 17.44 \\
& More than 5 years & 169.03 & 17.88 \\
\hline \multirow{2}{*}{ Total } & 1-5 years & 175.03 & 19.21 \\
& More than 5 years & 170.06 & 15.93 \\
\hline
\end{tabular}

To identify the differences, the researcher utilised the two-way ANOVATest. (See Table 10)

Table 10

ANOVA-Test for the Variables: Directorate and Experience, Applied in All Areas of the Study

\begin{tabular}{lccccc}
\hline Source of Variance & $\begin{array}{c}\text { Sum of } \\
\text { squares (SS) }\end{array}$ & $\begin{array}{c}\text { Freedom } \\
\text { Degree }\end{array}$ & $\begin{array}{c}\text { Squares' } \\
\text { Mean }\end{array}$ & T & $\begin{array}{c}\text { Sig. } \\
\text { Level }\end{array}$ \\
\hline Experience & 142.560 & 1 & 142.560 & .344 & .522 \\
$\begin{array}{l}\text { Directorate } \\
\begin{array}{l}\text { Interaction between experience } \\
\text { and the directorate. }\end{array}\end{array}$ & 144.890 & 2 & 72.445 & .277 & .789 \\
$\begin{array}{l}\text { Error } \\
\text { Total }\end{array}$ & 20128.105 & 98 & 205.388 & .745 & .290 \\
\hline
\end{tabular}

In conclusion, Table 10 did not show statistically significant differences attributed to the two variables (experience and directorate) in any of the study domains. The researchers explain this in that almost all the work situations are similar, allowing no role for the experience and directorate in the supervisor's performance as the work is predetermined and routine from the education directorates and supervision department. In fact, no creative work of the supervisor exists, nor is there the activation of the cognitive economy to which the Ministry of Education aspires. This result is in line with that of Al-Hailat and Alquda (2008), which did not show statistically significant differences in the degree of the supervisors' possession of the knowledge economy concepts, which 
may be ascribed to the experience variable. At the same time, it is not in line with the results of Alhulu's study (2009), which showed statistically significant differences attributed to the experience variable, which were in favour of those with ten and more years of experience. Finally, this study is also not in line with that of Altwaisi (2014), which showed statistically significant differences in the experience variable in favour of the supervisors with recent experience.

\section{Conclusion}

The researchers confirm that the performance of the educational supervisor in the light of the application of the concept of the knowledge economy in the directorates of education in Zarqa province was medium. Therefore, the researchers underscored the need to inform supervisors in the Ministry of Education of the characteristics and roles expected of them in schools in the transition to the knowledge economy. Through the holding of training courses, the Ministry of Education, explains to the supervisors how knowledge is generated, how to build and manufacture, how to improve the work and lead, the introduction of the principle of professional training for supervisors in the age of the knowledge economy in order to improve their professional and academic performance. The researchers also emphasised the necessity of training supervisors to think and train teachers on these issues, beyond the knowledge and creative practices of the supervisor, transferring them to the directorates and schools to teach them to teachers.

The study also indicates the importance of conducting more of these studies, including the roles of the headmaster, educational supervisor, and directors of education in the knowledge economy.

\section{Recommendations}

Based on the findings of this study and literature, the suggestions made for further research:

The Ministry of Education should review and adjust plans and areas of its educational supervision so that it will be able to achieve knowledge and skills required for the knowledge economy. Consequently, it should add new disciplines that improve and develop the educational professions and apply them in directorates of education.

There is a need to provide all the requirements of the knowledge economy, such as qualified supervisors, as well as material, finance, and moral support. 
The ministry should increase the effectiveness of the educational supervision in all areas through developing a sense of competition, advocated by the knowledge economy, between the directorates of education in the kingdom for those who provide the best level of educational supervision.

\section{References}

Atari, A. (2007). Role perceptions and role performance of instructional supervisors as perceived by teachers and supervisors in the public schools of Qatar. Durham, UK: University of Durham. Alhulu, G. H. (2009). Supervisory modes degree that practiced by supervisors in secondary schools from teachers' points of view in Palestine. Journal of Educational and Psychological Sciences, 10(3), $168-196$.

Alnnueaymi, F. (2007). Systematic program for the development of the institutional performance of the Directorates of Education and schools. Amman: National Library.

Alquda, S. M., \& M. Amin (2009). Attitudes government and secondary school principals and supervisors in the province of South Jordan towards professional development and training programs to achieve a knowledge-based economy. Journal of Human Sciences, 42(7), 124-151. Alssueud, R. (2002). Educational supervision: Modern trends. Amman: Tariq Center for University Services.

Altwaissi, A. (2014). The degree to which professional education teachers are practicing the knowledge economy skills, as perceived by the educational supervisors in Jordan. The Jordanian Journal of Educational science, 10(1), 37-54.

Al-Zagha, O. M. (1998). Educational supervision in the west bank as perceived by both the supervisor and the high school teacher. Nablus: An-Najah National University.

Beach, A. (2007). Perceptions of teachers, principals and supervision, of the instructional support services in the public school of Tennessee. Knoxville, TN: University of Tennessee.

Alsueud, R. (2002). Towards a future vision for the educational system in Jordan. Education forum in Jordan's future. Amman: Tarek University Services Center.

Hill, W. (1998). Evaluation of supervision. New York, NY: Mc Grow.

Khawaldeh, A. A. (2009). Towards a model of knowledge management at the Jordanian educational system. Journal of Educational and Psychological Sciences, 10(3), 89-109.

Musaeidah, W. A. (200o). Obstacles of educational supervision: From educational supervisors' perspectives in Northern Directorates of education. Irbid: Yarmouk University.

Mutaman, M. (2004). Role of the Jordanian educational system in the progress towards a knowledgebased economy. Teacher's Message, 43(1), 9-37.

Naranjo, F. V. De. (1991a). Educational supervision in Colombia: The role of the supervisor

(Dissertation abstract). Montreal: McGill University.

Pajak, E. (2002). Dimensions of supervision. Educational Leadership, 48(1), 78-81. 
Qutaifi, T. A. A. A. (1994). Problems of educational guidance in public secondary schools for girls.

Riyadh: King Saud University.

William, H. (2005). On being promoted: The transition to supervisor. Toronto: University of Toronto.

\section{Biographical note}

Mohammad Salman Fayyad Alkhazaleh, PhD, is an associate professor of educational administration at the Al Ain University for Science and Technology - College of Education, United Arab Emirates. He is a specialist in the fundamentals of education, educational administration, curricula and teaching methods.

Habes Mohammed Khalifa Hattamleh, $\mathrm{PhD}$, is an associate professor of Educational Origins at the Faculty of Education, University of Jadara, Jordan. He teaches several undergraduate, graduate and doctoral educational courses. He is currently the Dean of the Faculty of Education and Assistant to the President of Jadra University. 